\title{
Isolation and Purification of Sugarcane Waxes from Sugarcane Peels and Filter Cake Mud
}

\section{Adel M. Kamal El-Dean ${ }^{a}$, Ahmed A. Geies ${ }^{a}$, Salah Ali Masaod ${ }^{b}$ and Shimaa M. El-Ameen ${ }^{\mathrm{a}}$}

${ }^{a}$ Chemistry Department, Faculty of Science, Assiut University, Assiut, Egypt

${ }^{b}$ Egyptian Sugar \& Integrated Industries Company (ESIIC), Egypt E-mail:shosho90rose@yahoo.com

\begin{abstract}
Sugarcane bagasse was collected from different sources(from local juice centre, Egyptian Sugar \& Integrated Industries Company, The residue of the sugar production and by scratching of sugarcane). The waxes were extracted using different solvents (water, ethanol, n-hexane, toluene and methylene chloride). The waxes obtained from each solvent containing different components. The extracted waxes were crystallized and then carrying out different analyses for each fraction of them (FT-IR, H NMR and GC-MS spectra), depending on the analyses we determined the wax components.
\end{abstract}

Keywords: Sugarcane bagasse, Filter cake mud, Waxes, Scratching, Isolation.

\section{Introduction:}

Sugarcane (Saccharumofficinarum L.) is an important economic plant. The area planted with the sugarcane in Egypt about125000 Hectares = 297619.047 Feddanproducing about 12.5 MMT of sugar cane [1].

Egyptian Sugar \& Integrated Industries Company tries to maximize the utilization of all components of sugarcane. The integrated industry policy makes the sugar company to use all the byproducts of sugar industry. The sugarcane bagasse used as raw materials for paper and fiber board industries. Molasses used in the production of different important chemicals (ethanol, acetone, acetic acid, butanol, yeasts) and other chemicals. Filter cake mud was used as fertilizer. 
In the light of the sugar companies policy and the policy of the Sugar Technology Collage, we found that there is a product no less important than previous products must be taken in consideration. This product is sugarcane waxes as, a whitish to dark yellowish coating on the surface of sugarcane which gets extracted and separated along with press mud during crushing and processing of the cane juice. This wax portion finds applications in cosmetics, paper coating, textiles, fruit and vegetable coating, leather sizing, lubricants, adhesives, polishes, and pharmaceutical industry[2-4].

In the filter cake is observed an average order of wax and raw lipids from 5 to $14 \%$ on a dry basis with different proposals for their use but they often are sent to fields as fertilizer in the six weeks prior to planting grass[5]. During the grinding rod, about $40 \%$ of lipid material is dispersed in the juice as sludge while the remainder is retained in the pulp after the grinding [6].

Sugarcane wax has always been a matter of interest, due to its industrial applications, in particular in the cosmetic and pharmaceutical industry (Taylor, 2000) [4]. It is a potential substitute for costly carnauba wax widely used in cosmetics, foods and pharmaceuticals. In addition, sugarcane wax is also a source of long chain primary aliphatic alcohols as Policosanol PC which are a waxy material that are high-Mw aliphatic alcohols with chain lengths that vary from 24 to 34 carbon atoms. The most common sources of policosanols used for nutritional supplements are sugarcane. The most components of PC are octacosanol (C28), triacontanol (C30) and hexacosanol (C26)). These compounds were first approved as a dietary supplement, which find applications as cholesterol-lowering products (Laguna Granja et al., 1999 [7]; Mas et al., 1999[8]). During the agro-industrial process, a large part of the wax is dissolved in the crude juice, and then removed in the wastes during the subsequent defecation-clarification step (filter cake from sugar refinery) or distillation (fermentation wastes and vinasses).

Wax recovery from filter cake is well documented (Paturau, 1989) [9] as the relevant methods and techniques at the laboratory or industrial level (Lamberton and Radcliffe, 1965; [10, 11] Parfait, 1997 [12]; Askew et al., 1999) [13], [14]. Octacosanol is a 
main component of policosanols, the fatty alcohol mixture, found in plant waxes common in fruits, leaves, surface of plants, and whole seeds.

In the light view of the previous benefits of sugarcane waxes, we decide to extract and isolate the sugarcane waxes from both sugarcane bagasse and filter cake mud and we are sure that represents an added value to the sugar industry in Egypt.

\section{Material and Methods}

1. Sugarcane peels were collected from local sugarcane juice shops in Assiut city, also by the sugarcane peeling or by scrape the outer crust of sugarcane stalks.

2. Soxhlet extractor to carrying out the waxes extraction processes.

3. Solvents: Distilled water provided from the Chemistry Department, Assiut University. Also, toluene, ethanol, methylene chloride were purchased from Sigma-Aldrich Co.

\section{Analyses}

The Fourier transform infrared (FTIR) spectra were recorded using potassium bromide disks on a FT-IR 8201 PC Shimadzu. A Bruker $400 \mathrm{MHz}$ and Varian $90 \mathrm{MHz}$ spectrometers were used to measure ${ }^{1} \mathrm{H}$ NMR spectra in the presence of tetramethylsilane as an internal standard. Chemical shifts were measured in ppm. Gas-Mass (GC/MS) detection, an electron ionization system with ionization energy of $70 \mathrm{eV}$ was used at Chemistry Department, Assiut University.

\section{Experimental and procedures}

Extraction of wax from sugarcane peel provided from the sugarcane juice centers:

Preparation of samples: Sugarcane peels are first removed and shredding surface of sugarcane before crushing and pressed for the juice in case of juice processed for the retail market. Thus, it was comprehended that if one removes peel before juice processing, extraction of wax would be a much easier and cleaner process. Sugarcane peels were collected from some local juice centers. The waste material was first dried in sunlight and then pickling and sieved in a mesh sieve 


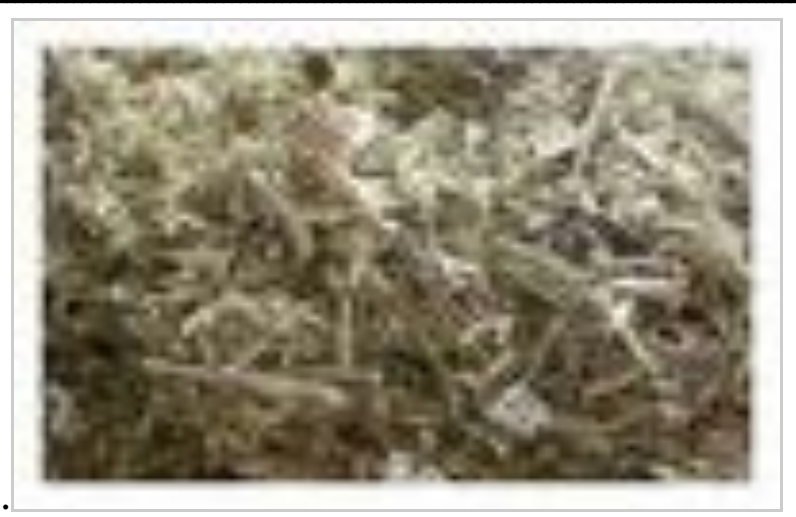

\section{Extraction by water}

Dried sugarcane peels (22 g), put them in cartouche and introducing to the soxhlet extractor. Water $(200 \mathrm{ml})$ in a $(500 \mathrm{ml})$ round bottomed flask was connected to the soxhlet extractor and heating using heating mantle at $100{ }^{\circ} \mathrm{C}$ for $8-10$ hours. The extraction process was repeated three times without change the solvent using another quantity and the same weight of sugarcane peels at each time.

Solvent was evaporated using rotatory evaporator and the residue contained wax mixtures with some impurities.

\begin{tabular}{|l|l|l|l|}
\hline Trial No. & $\begin{array}{l}\text { Weight before } \\
\text { extraction }\end{array}$ & $\begin{array}{l}\text { Weight after } \\
\text { extraction }\end{array}$ & $\begin{array}{l}\text { Difference } \\
\text { in weight }\end{array}$ \\
\hline 1 & $22.59 \mathrm{~g}$ & $20.55 \mathrm{~g}$ & $2.04 \mathrm{~g}$ \\
\hline 2 & $22.59 \mathrm{~g}$ & $19.34 \mathrm{~g}$ & $\mathbf{3 . 2 5} \mathrm{g}$ \\
\hline 3 & $22.59 \mathrm{~g}$ & $20.03 \mathrm{~g}$ & $2.55 \mathrm{~g}$ \\
\hline total & $67.77 \mathrm{~g}$ & $59.92 \mathrm{~g}$ & $\mathbf{7 . 8 5} \mathrm{g}$ \\
\hline
\end{tabular}

The weight of wax extracted from sugar cane peelis $7.85 \mathrm{~g}$.

The $\%$ of waxes $=7.85 \times 100 / 67.77=11.58 \%$ yield

Melting point $=82{ }^{\circ} \mathrm{C}$.

IR: $v=3400 \mathrm{~cm}^{-1}\left(\mathrm{OH}\right.$ carboxylic group),2950 $\mathrm{cm}^{-1}$ ( $\mathrm{CH}$ aliphatic), $1700 \mathrm{~cm}^{-1}$ (CO group).

\section{Extraction of wax from sugarcane peel by toluene:}

The procedure in the previous experiment was repeated with using of toluene as a solvent instead of water. 
The results summarized in the following Table.

\begin{tabular}{|l|l|l|l|}
\hline Trial No. & $\begin{array}{l}\text { Weight before } \\
\text { extraction }\end{array}$ & Weight after extraction & $\begin{array}{l}\text { Difference } \\
\text { in weight }\end{array}$ \\
\hline 1 & $22.59 \mathrm{~g}$ & $20.75 \mathrm{~g}$ & $1.84 \mathrm{~g}$ \\
\hline 2 & $22.59 \mathrm{~g}$ & $20.63 \mathrm{~g}$ & $1.96 \mathrm{~g}$ \\
\hline 3 & $22.59 \mathrm{~g}$ & $20.64 \mathrm{~g}$ & $1.95 \mathrm{~g}$ \\
\hline total & $67.77 \mathrm{~g}$ & $62.02 \mathrm{~g}$ & $5.75 \mathrm{~g}$ \\
\hline
\end{tabular}

The weight of wax extracted from sugar cane peel is5.750g. The $\%$ of waxes $=5.750 / 67.77 \mathrm{X} 100=8.48 \%$ yield, m.p. $73{ }^{\circ} \mathrm{C}$. IR: $v=3426 \mathrm{~cm}^{-1}$ broad band $(\mathrm{OH}), 2917 \mathrm{~cm}^{-1}$ ( $\mathrm{CH}$ aliphatic), 1712 $\mathrm{cm}^{-1}(\mathrm{C}=\mathrm{O})$.

H NMR $(90 \mathrm{MHz})\left(\mathrm{CDCl}_{3}\right): \delta=0,8\left(\mathrm{t}, 3 \mathrm{H}, \mathrm{CH}_{3}\right), 3.98(\mathrm{~s}, 1 \mathrm{H}, \mathrm{OH}$ alcoholic), 2.35, 2.6, 1.54, 1.18 for $\left(\mathrm{m}, 54 \mathrm{H}, 27 \mathrm{CH}_{2}\right)$.

GC/MS spectrum showed different signal related to long chain unsaturated hydrocarbons 9-eicosene, octacosene ( which were produced from the loss of water molecule from long chain alcohols) and long chain fatty acid e.g. octadecanoic acid and its ethyl ester, 1-eicosanol.

\section{Extraction of wax from sugarcane peel by n-hexane:}

The procedure in the previous experiment was repeated by using of n-hexane as a solvent.

The results summarized in the following Table.

\begin{tabular}{|c|c|c|c|}
\hline Trial No. & $\begin{array}{l}\text { Weight before } \\
\text { extraction }\end{array}$ & $\begin{array}{l}\text { Weight after } \\
\text { extraction }\end{array}$ & $\begin{array}{l}\text { Difference } \\
\text { in weight }\end{array}$ \\
\hline 1 & $22.59 \mathrm{~g}$ & $21.46 \mathrm{~g}$ & $1.13 \mathrm{~g}$ \\
\hline 2 & $22.59 \mathrm{~g}$ & $21.45 \mathrm{~g}$ & $1.14 \mathrm{~g}$ \\
\hline 3 & $22.59 \mathrm{~g}$ & $21.45 \mathrm{~g}$ & $1.14 \mathrm{~g}$ \\
\hline total & $67.78 \mathrm{~g}$ & $64,36 \mathrm{~g}$ & $3.41 \mathrm{~g}$ \\
\hline
\end{tabular}

The weight of wax extracted from sugar cane peel is $3.41 \mathrm{~g}$. $\%$ Waxes $=3.4 / 67.78 \times 100=5.02 \%$ yield, m.p. $84{ }^{\circ} \mathrm{C}$.

IR: $v=3426 \mathrm{~cm}^{-1}$ broad band $(\mathrm{OH}), 2917 \mathrm{~cm}^{-1} \quad(\mathrm{CH}$ aliphatic), $1736 \mathrm{~cm}^{-1}(\mathrm{C}=\mathrm{O})$

GC/MS: Base peak at 57.1 and molecular ion peak at 446.5, and other fragments related to long chain saturated and unsaturated hydrocarbons e.g., n-octacosane,1-octacosene, 1-heptacosene and 1- 
hexacosene (which were produced from the loss of water molecule from long chain alcohols).

${ }^{1} \mathrm{H} \mathrm{NMR} 90 \mathrm{MHz}\left(\mathrm{CDCl}_{3}\right): \delta=0.9\left(\mathrm{t}, 3 \mathrm{H}, \mathrm{CH}_{3}\right)$ and at $1.3(\mathrm{~m}, 54 \mathrm{H}$, $27 \mathrm{CH}_{2}$ ).

\section{Extraction of wax from sugarcane peel by ethanol (95\%):}

The procedure in the previous experiment was repeated with using of ethanol (95\%) as a solvent.

The results summarized in the following Table.

\begin{tabular}{|c|c|c|c|}
\hline $\begin{array}{c}\text { Trial } \\
\text { No. }\end{array}$ & $\begin{array}{l}\text { Weight before } \\
\text { extraction }\end{array}$ & $\begin{array}{l}\text { Weight after } \\
\text { extraction }\end{array}$ & $\begin{array}{l}\text { Difference } \\
\text { in weight }\end{array}$ \\
\hline 1 & $22.59 \mathrm{~g}$ & $18.44 \mathrm{~g}$ & $4.14 \mathrm{~g}$ \\
\hline 2 & $22.59 \mathrm{~g}$ & $17.76 \mathrm{~g}$ & $4.81 \mathrm{~g}$ \\
\hline 3 & $22.59 \mathrm{~g}$ & $20.27 \mathrm{~g}$ & $2.32 \mathrm{~g}$ \\
\hline total & $67.72 \mathrm{~g}$ & $57.32 \mathrm{~g}$ & $10.45 \mathrm{~g}$ \\
\hline
\end{tabular}

The weight of wax extracted from sugar cane peel is $10.45 \mathrm{~g}$. $\%$ Waxes $=10.45 / 67.78 \mathrm{X} 100=15.41 \%$ yield, melting point $82^{\circ} \mathrm{C}$ IR: $v=3419 \mathrm{~cm}^{-1}$ broad band $(\mathrm{OH}), 2917 \mathrm{~cm}^{-1}$ (CH aliphatic), 1737 $\mathrm{cm}^{-1}(\mathrm{C}=\mathrm{O})$

${ }^{1} \mathrm{H} \mathrm{NMR} 90 \mathrm{MHz}\left(\mathrm{CDCl}_{3}\right): \delta=0.9\left(\mathrm{t}, 3 \mathrm{H}, \mathrm{CH}_{3}\right)$ and at $1.3(\mathrm{~m}, 54 \mathrm{H}$, $27 \mathrm{CH}_{2}$ ).

\section{Extraction of wax from sugarcane peel by methylene chloride:}

The procedure in the previous experiment was repeated with using of methylene chloride as a solvent.

The results summarized in the following Table.

\begin{tabular}{|c|c|c|c|}
\hline Trial No. & $\begin{array}{l}\text { Weight before } \\
\text { extraction }\end{array}$ & $\begin{array}{l}\text { Weight after } \\
\text { extraction }\end{array}$ & $\begin{array}{l}\text { Difference } \\
\text { in weight }\end{array}$ \\
\hline 1 & $22.59 \mathrm{~g}$ & $16.98 \mathrm{~g}$ & $5.61 \mathrm{~g}$ \\
\hline 2 & $22.59 \mathrm{~g}$ & $19.74 \mathrm{~g}$ & $2.85 \mathrm{~g}$ \\
\hline 3 & $22.59 \mathrm{~g}$ & $17.32 \mathrm{~g}$ & $5.26 \mathrm{~g}$ \\
\hline total & $67.78 \mathrm{~g}$ & $54.04 \mathrm{~g}$ & $13.73 \mathrm{~g}$ \\
\hline
\end{tabular}

The weight of wax extracted from sugar cane peel is $13.73 \mathrm{~g}$. $\%$ waxes $=13.73 / 67.78 \times 100=20.25 \%$ yield, melting point $83{ }^{\circ} \mathrm{C}$. IR: $v=3419 \mathrm{~cm}^{-1}$ broad band $(\mathrm{OH}), 2917 \mathrm{~cm}^{-1}$ ( $\mathrm{CH}$ aliphatic), 1736 $\mathrm{cm}^{-1}(\mathrm{C}=\mathrm{O})$ 
${ }^{1} \mathrm{H}$ NMR $400 \mathrm{MHz}\left(\mathrm{CDCl}_{3}\right): \delta=0.9\left(\mathrm{t}, 3 \mathrm{H}, \mathrm{CH}_{3}\right), 1.3(\mathrm{~m}, 54 \mathrm{H}, 27$ $\mathrm{CH}_{2}$ ) and at $3.6(\mathrm{~s}, 1 \mathrm{H}, \mathrm{OH})$.

GC/MS spectrum showed different signal related to long chain saturated and unsaturated hydrocarbons e.g, n-octacosane , 1octacosene, 1-heptacosene and 1-hexacosene( which were produced from the loss of water molecule from long chain alcohols) and long chain fatty acid e.g., octadecanoic acid and its ethyl ester, 1eicosanol.

MS spectra m/z: Base peak at 97.1 and other peaks at m/z 410 and 392 due to octacosanol and its dehydrated 1-octacosene respectively.

\section{Extraction of wax from press mud of sugarcane}

Preparation of samples: We are obtained the press mud of sugarcane from some sugarcane factories of the sugar industry. It was first dried in sunlight and grounded.

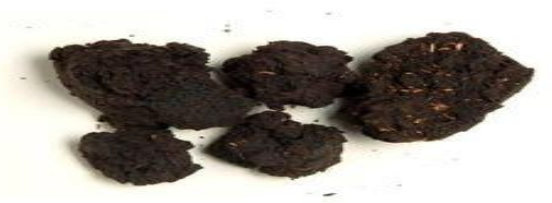

- Extraction of wax from press mud by methylene chloride

Dried powder of press mud (22 g) using a soxhlet extractor and (200 $\mathrm{ml})$ of methylene chloride in a $(250 \mathrm{ml})$ round bottomed flask at 80 ${ }^{\circ} \mathrm{C}$ for 8-10 hours using heating mantel. The extraction process was repeated three times without change the solvent using another quantity and the same weight of sugarcane press mud at each time. Solvent was evaporated using rotatory evaporator and the residue contained wax mixtures with some impurities was collected.

The results summarized in the following Table.

\begin{tabular}{|l|l|l|l|}
\hline Trial No. & $\begin{array}{l}\text { Weight before } \\
\text { extraction }\end{array}$ & $\begin{array}{l}\text { Weight after } \\
\text { extraction }\end{array}$ & $\begin{array}{l}\text { Difference } \\
\text { in weight }\end{array}$ \\
\hline 1 & $22.59 \mathrm{~g}$ & $21.08 \mathrm{~g}$ & $1.51 \mathrm{~g}$ \\
\hline 2 & $22.59 \mathrm{~g}$ & $21.40 \mathrm{~g}$ & $1.18 \mathrm{~g}$ \\
\hline 3 & $22.59 \mathrm{~g}$ & $20.08 \mathrm{~g}$ & $2.50 \mathrm{~g}$ \\
\hline total & $67.77 \mathrm{~g}$ & $62.56 \mathrm{~g}$ & $5.20 \mathrm{~g}$ \\
\hline
\end{tabular}


The weight of wax extracted from press mud of sugarcane is $5.2 \mathrm{~g}$ The $\%$ of waxes $=5.20 \times 100 / 67.77=7.67 \%$ yield, melting point $79^{\circ} \mathrm{C}$.

IR: $v=3418.95 \mathrm{~cm}^{-1}$ (OH group), $2917.56 \mathrm{~cm}^{-1}$ (CH aliphatic), $1736.99 \mathrm{~cm}^{-1}$ (CO group).

${ }^{1} \mathrm{H}$ NMR $400 \mathrm{MHz}\left(\mathrm{CDCl}_{3}\right): \delta=0.9\left(\mathrm{t}, 3 \mathrm{H}, \mathrm{CH}_{3}\right), 1.3(\mathrm{~m}, 54 \mathrm{H}, 27$ $\mathrm{CH}_{2}$ ) and at $3.6(\mathrm{~s}, 1 \mathrm{H}, \mathrm{OH})$.

MS Spectra: Base peak at 97.2 and molecular ion peak at552.8 and other peaks at m/z 410 and 392 due to octacosanol and its dehydrated 1-octacosene, respectively.

Extraction from press mud of sugarcane by ethanol (95\%):

The procedure in the previous experiment was repeated with using ofethanol (95\%)as a solvent.

The results summarized in the following Table.

\begin{tabular}{|c|c|c|c|}
\hline $\begin{array}{c}\text { Trial } \\
\text { No. }\end{array}$ & $\begin{array}{l}\text { Weight before } \\
\text { extraction }\end{array}$ & $\begin{array}{l}\text { Weight after } \\
\text { extraction }\end{array}$ & $\begin{array}{l}\text { Difference } \\
\text { in weight }\end{array}$ \\
\hline 1 & $22.59 \mathrm{~g}$ & $21.28 \mathrm{~g}$ & $1.30 \mathrm{~g}$ \\
\hline 2 & $22.56 \mathrm{~g}$ & $21.52 \mathrm{~g}$ & $1.04 \mathrm{~g}$ \\
\hline 3 & $22.59 \mathrm{~g}$ & $21.68 \mathrm{~g}$ & $\mathbf{0 . 9 0} \mathrm{g}$ \\
\hline Total & $67.74 \mathrm{~g}$ & $64.48 \mathrm{~g}$ & $3.26 \mathrm{~g}$ \\
\hline
\end{tabular}

The weight of wax extracted from press mud of sugarcane is $3.24 \mathrm{~g}$ $\%$ waxes $=3.26 / 67.74 . X 100=4.81 \%$ yield, melting point $78^{\circ} \mathrm{C}$.

IR: $v=3363.47 \mathrm{~cm}^{-1}$ broad band $(\mathrm{OH}), 2917.23 \mathrm{~cm}^{-1}(\mathrm{CH}$ aliphatic $)$, $1716.20 \mathrm{~cm}^{-1}$ (CO group).

${ }^{1} \mathrm{H} \mathrm{NMR} 90 \mathrm{MHz}\left(\mathrm{CDCl}_{3}\right): \delta=0.9\left(\mathrm{t}, 3 \mathrm{H}, \mathrm{CH}_{3}\right)$ and at $1.3(\mathrm{~m}, 54 \mathrm{H}$, $27 \mathrm{CH}_{2}$ ).

\section{Extraction of wax from press mud by n-hexane}

The procedure in the previous experiment was repeated with using ofhexane as a solvent. 
The results summarized in the following Table.

\begin{tabular}{|c|c|c|c|}
\hline Trial No. & $\begin{array}{l}\text { Weight before } \\
\text { extraction }\end{array}$ & $\begin{array}{l}\text { Weight after } \\
\text { extraction }\end{array}$ & $\begin{array}{l}\text { Difference } \\
\text { in weight }\end{array}$ \\
\hline 1 & $22.59 \mathrm{~g}$ & $21.86 \mathrm{~g}$ & $\mathbf{0 . 7 2} \mathrm{g}$ \\
\hline 2 & $22.59 \mathrm{~g}$ & $21.95 \mathrm{~g}$ & $\mathbf{0 . 6 3 9}$ \\
\hline 3 & $22.59 \mathrm{~g}$ & $22.25 \mathrm{~g}$ & $\mathbf{0 . 3 3} \mathrm{g}$ \\
\hline Total & $67.77 \mathrm{~g}$ & $66.06 \mathrm{~g}$ & $1.71 \mathrm{~g}$ \\
\hline
\end{tabular}

The weight of wax extracted from press mud is $1.71 \mathrm{~g}$ $\%$ waxes $=1.71 / 67.77 \mathrm{X} 100=2.52 \%$ yield, melting point $83^{\circ} \mathrm{C}$ IR: $v=3422 \mathrm{~cm}^{-1}$ broad band $(\mathrm{OH}), 2917 \mathrm{~cm}^{-1}(\mathrm{CH}$ aliphatic $), 1735$ $\mathrm{cm}^{-1}$ (CO group).

${ }^{1} \mathrm{H}$ NMR $400 \mathrm{MHz}\left(\mathrm{CDCl}_{3}\right): \delta=0.9\left(\mathrm{t}, 3 \mathrm{H}, \mathrm{CH}_{3}\right), 1.3(\mathrm{~m}, 54 \mathrm{H}, 27$ $\left.\mathrm{CH}_{2}\right)$ and at $3.6(\mathrm{~s}, 1 \mathrm{H}, \mathrm{OH})$.

MS Base peak at 97.1 and molecular ion peak at 539, and other fragments at m/z 410 and 392 due to octacosanol and its dehydrated 1-octacosene respectively. Other $\mathrm{m} / \mathrm{z}$ for heptacosanol and hexacosanol also present.

Extraction of wax from press mud by toluene

The procedure in the previous experiment was repeated with using of toluene as a solvent.

The results summarized in the following Table.

\begin{tabular}{|c|c|c|c|}
\hline $\begin{array}{c}\text { Trial } \\
\text { No. }\end{array}$ & $\begin{array}{l}\text { Weight before } \\
\text { extraction }\end{array}$ & $\begin{array}{l}\text { Weight after } \\
\text { extraction }\end{array}$ & $\begin{array}{l}\text { Difference } \\
\text { in weight }\end{array}$ \\
\hline 1 & $22.60 \mathrm{~g}$ & $21.75 \mathrm{~g}$ & $0.85 \mathrm{~g}$ \\
\hline 2 & $22.57 \mathrm{~g}$ & $21.77 \mathrm{~g}$ & $0.80 \mathrm{~g}$ \\
\hline 3 & $22.59 \mathrm{~g}$ & $20.99 \mathrm{~g}$ & $1.59 \mathrm{~g}$ \\
\hline total & $67.76 \mathrm{~g}$ & $64.51 \mathrm{~g}$ & $3.25 \mathrm{~g}$ \\
\hline
\end{tabular}

The weight of wax extracted from press mud (practically) is $3.25 \mathrm{~g}$ $\%$ Waxes $=3.25 / 67.76 \mathrm{X} 100=4.79 \%$ yield, melting point $74^{\circ} \mathrm{C}$

IR: $v=3381 \mathrm{~cm}^{-1}$ broad band $(\mathrm{OH}), 2917 \mathrm{~cm}^{-1}$ (CH aliphatic), 1715 $\mathrm{cm}^{-1}$ (CO group).

${ }^{1} \mathrm{H} \mathrm{NMR} 90 \mathrm{MHz}\left(\mathrm{CDCl}_{3}\right): \delta=0.9\left(\mathrm{t}, 3 \mathrm{H}, \mathrm{CH}_{3}\right)$ and at $1.3(\mathrm{~m}, 54 \mathrm{H}$, $27 \mathrm{CH}_{2}$ )

GC/MS: Base peak at 57.1 and molecular ion peak at 429, and other fragments at m/z 392,390, 364. 


\section{Results and discussion}

Sugarcane waxes commonly exists in the surface of plants, part of these waxes remained in the sugarcane bagasse and its majority gone with juice and after industrial processes gone to the filter cake mud.

In the present work we aimed to isolate and purify of sugarcane waxes from three stages of sugarcane treatment processes.

The sugarcane waxes for this study obtained from three sources:

1. From the sugarcane peels by shredding surface of sugarcane before crushing and pressed for the juice in case of juice processed for the retail market.

2. From sugarcane bagasse after crushing and pressed for the juice in case of juice processed for the retail market.

3. From filter cake mud provided from sugar companies.

The analyses of the waxes obtained from the three sources showed that the obtained wax is a mixture of hydrocarbons, alcohols, aldehydes and carboxylic acids.

From the previous processes, in the first case we extracted the waxes from sugarcane peels with toluene. The $\%$ of waxes obtained $=8.48 \%$ yield relative to the sugarcane peels used. The waxes mixture m.p. is $73{ }^{\circ} \mathrm{C}$.

From its IR and mass spectra, it appeared that it containing long chain fatty carboxylic acid and alcohols while their revealed absorption bands at $3450 \mathrm{~cm}^{-1}$ broad band $(\mathrm{OH}), 2900 \mathrm{~cm}^{-1}(\mathrm{CH}$ aliphatic), $1700 \mathrm{~cm}^{-1}(\mathrm{C}=\mathrm{O})$.

GC/MS spectrum showed a molecular ion peak at $\mathrm{m} / \mathrm{z}=494$ that is indicate to the presence of $\mathrm{CH}_{3}\left(\mathrm{CH}_{2}\right)_{31} \mathrm{COOH}$ with ratio at $0.02 \%$; and other fragment at $\mathrm{m} / \mathrm{z}=454$ for $\mathrm{CH}_{3}\left(\mathrm{CH}_{2}\right)_{28} \mathrm{CO}_{2} \mathrm{H}$ with ratio at $0.02 \%$; at $\mathrm{m} / \mathrm{z}=438$ with ratio at $0.06 \mathrm{CH}_{3}\left(\mathrm{CH}_{2}\right)_{27} \mathrm{CO}_{2} \mathrm{H}$ in Addition to alcohols Octacosanol $\left(\mathrm{CH}_{3}\left(\mathrm{CH}_{2}\right)_{26} \mathrm{CH}_{2} \mathrm{OH}\right)$ at $\mathrm{m} / \mathrm{z}=410$ with ratio at $0.11 \%$; Docosanol $\mathrm{CH}_{3}\left(\mathrm{CH}_{2}\right)_{20} \mathrm{CH}_{2} \mathrm{OH}$ at $\mathrm{m} / \mathrm{z}=326$ and with ratio at $0.12 \%$; Tetracosanol $\mathrm{CH}_{3}\left(\mathrm{CH}_{2}\right)_{22} \mathrm{CH}_{2} \mathrm{OH}$ at $\mathrm{m} / \mathrm{z}=354$ with ratio at $0.07 \%$; Hexacosanol at $\mathrm{m} / \mathrm{z}=382$ with ratio at $0.17 \%$; Hexacosanol $\mathrm{CH}_{3}\left(\mathrm{CH}_{2}\right)_{24} \mathrm{CH}_{2} \mathrm{OH}$ at $\mathrm{m} / \mathrm{z}=396$ with ratio at $0.09 \%$; Nonacosanol $\mathrm{CH}_{3}\left(\mathrm{CH}_{2}\right)_{27} \mathrm{CH} 2 \mathrm{OH}$ at $\mathrm{m} / \mathrm{z}=424$ with ratio 
at $0.16 \%$; Triacontanol $\mathrm{CH}_{3}\left(\mathrm{CH}_{2}\right)_{28} \mathrm{CH}_{2} \mathrm{OH}$ at $\mathrm{m} / \mathrm{z}=438=0.13$ in addition to alkanes (Triptane) 2,2,3-Trimethylbutaneat $\mathrm{m} / \mathrm{z}=100$ with ratio at $17 \%$;

Fatty acids Hexadecanoic acid $\mathrm{CH}_{3}\left(\mathrm{CH}_{2}\right)_{14} \mathrm{COOH}$ at $\mathrm{m} / \mathrm{z}=$ 256 with ratio at $0.27 \%$; Octadecanoic acid at $\mathrm{m} / \mathrm{z}=284$ with ratio at $0.12 \%$; octadeca-9, 12-dienoic acid at $\mathrm{m} / \mathrm{z}=280$ with ratio at 0.33 ; 9-Tetradecenoic acid at $\mathrm{m} / \mathrm{z}=226$ ratio at $0.82 \%$; Octacosanoic acid $\mathrm{CH}_{3}\left(\mathrm{CH}_{2}\right)_{26} \mathrm{CO}_{2} \mathrm{H} \mathrm{C}_{28} \mathrm{H}_{56} \mathrm{O}_{2}$ at $\mathrm{m} / \mathrm{z}=424$ with ratio at $0.16 \%$.

$\mathrm{H}^{1} \mathrm{NMR}\left(90 \mathrm{MHz}, \mathrm{CDCl}_{3}\right.$ ) showed signals (t, at 3.57), 3.98 for $\mathrm{OH}$ alcoholic, 2.35, 2.6, 1.54, 1.18 for $\mathrm{CH}_{2}$, and $0.8(\mathrm{t})$ for $\left(\mathrm{CH}_{3}\right)$.

When the sugarcane wax extracted with ethanol (95\%), we obtained a waxes mixture with m.p at $82{ }^{\circ} \mathrm{C}$ with yield $15.41 \%$ relative to the quantity of sugar peels used. From its analyses, we found it a mixture of different compounds including long chain alcohols and carboxylic acids. Its IR showed an absorption bands at $3419 \mathrm{~cm}^{-1}$ broad band $(\mathrm{OH}), 2917 \mathrm{~cm}^{-1}$ (CH aliphatic), $1736 \mathrm{~cm}^{-1}$. 
The other fragmentations which we can identified was listed in the following Table:

\begin{tabular}{|c|c|c|c|}
\hline $\mathbf{m} / \mathbf{z}$ & fragment & $\begin{array}{l}\text { Intensity } \\
\%\end{array}$ & Structure \\
\hline \multicolumn{4}{|c|}{ Alcohols } \\
\hline & n-Tetracosanol & 0.05 & $\left(\mathrm{n}-\mathrm{C}_{24} \mathrm{H}_{49} \mathrm{OH}(354.66)\right)$ \\
\hline & n-Hexacosanol & .02 & $n-C_{26} H_{53} \mathrm{OH}(382.71)$ \\
\hline & n-Octacosanol & 0.14 & $\mathrm{n}-\mathrm{C}_{28} \mathrm{H}_{57} \mathrm{OH}(410.77)$ \\
\hline & n-Nonacosanol & 0.02 & n-C29H59O(424.79) \\
\hline & n-Triacontanol & 0.15 & $n-C_{30} H_{61} \mathrm{OH}(438.82)$ \\
\hline & n-Dotriacontanol & 0.02 & $n-C_{32} H_{65} \mathrm{OH}(466.88)$ \\
\hline & n-Tetratriacontanol & 0.01 & $\mathrm{n}-\mathrm{C}_{34} \mathrm{H}_{69} \mathrm{OH}(494.93)$ \\
\hline \multicolumn{4}{|c|}{ Fatty carboxylic acids } \\
\hline & n-Hexacosanoic & 0.03 & \\
\hline & n-Octacosanoic & 0.02 & $\begin{array}{l}\mathrm{CH}_{3}\left(\mathrm{CH}_{2}\right)_{26} \mathrm{CO}_{2} \mathrm{H} \\
\mathrm{C}_{28} \mathrm{H}_{56} \mathrm{O}_{2}=424.75\end{array}$ \\
\hline & n-Nnonacosanoic & 015 & $\begin{array}{l}\mathrm{CH}_{3}\left(\mathrm{CH}_{2}\right)_{27} \mathrm{CO}_{2} \mathrm{H} \\
438.8 \mathrm{C}_{29} \mathrm{H}_{58} \mathrm{O}_{2}\end{array}$ \\
\hline & n-Triacontanoic & 0.01 & $\mathrm{C}_{30} \mathrm{H}_{60} \mathrm{O}_{2} 452.46$ \\
\hline & n-Dotriacontanoic & 0.01 & $\begin{array}{l}\mathrm{C}_{32} \mathrm{H}_{64} \mathrm{O}_{2}(480.86) \\
\mathrm{CH}_{3}\left(\mathrm{CH}_{2}\right)_{30} \mathrm{CO}_{2} \mathrm{H}\end{array}$ \\
\hline & n-etratriacontanoic & 0.01 & $\begin{array}{l}\mathrm{C}_{34} \mathrm{H}_{68} \mathrm{O}_{2}(508.91) \\
\mathrm{CH}_{3}\left(\mathrm{CH}_{2}\right)_{32} \mathrm{CO}_{2} \mathrm{H}\end{array}$ \\
\hline
\end{tabular}

When the sugar cane peels was extracted with methylene chloride the yield of crude waxes about $20.26 \%$ relative to the sugarcane peels used, m.p. $83{ }^{\circ} \mathrm{C}$.

$\%$ Waxes $=13.7321 / 67.7818 \times 100=20.2592 \%$ yield, melting point $83{ }^{\circ} \mathrm{C}$.

The IR: $v=3419 \mathrm{~cm}^{-1}$ broad band $(\mathrm{OH}), 2917 \mathrm{~cm}^{-1}$ (CH aliphatic), $1736 \mathrm{~cm}^{-1}(\mathrm{C}=\mathrm{O})$

${ }^{1} \mathrm{H} \mathrm{NMR} 90 \mathrm{MHz}\left(\mathrm{CDCl}_{3}\right): \delta=0.9\left(\mathrm{t}, 3 \mathrm{H}, \mathrm{CH}_{3}\right)$ and at $1.3(\mathrm{~m}, 54 \mathrm{H}$, $27 \mathrm{CH}_{2}$ ).

${ }^{1} \mathrm{H}$ NMR $400 \mathrm{MHz}\left(\mathrm{CDCl}_{3}\right): \delta=0.9\left(\mathrm{t}, 3 \mathrm{H}, \mathrm{CH}_{3}\right), 1.3(\mathrm{~m}, 54 \mathrm{H}, 27$ $\left.\mathrm{CH}_{2}\right)$ at $3.6\left(\mathrm{CH}_{2}-\mathrm{OH}\right)$, and 9.29, 9.69 (s, H, carboxylic group). 
Gas mass spectrum showed a molecular ion peak at $\mathrm{m} / \mathrm{z}=538$, and base peak at $\mathrm{m} / \mathrm{z}=97.1$

The fragmentation pattern of gas mass spectrum showed that the waxes are composed of a mixture of hydrocarbons, aldehydes, alcohols and carboxylic acids.

The other fragmentations identified were listed in the following Table:

\begin{tabular}{|c|c|c|c|}
\hline $\mathbf{m} / \mathbf{z}$ & fragments & Intensity \% & Structure \\
\hline 41 & \multicolumn{3}{|c|}{ Aldehydes } \\
\hline & n-Tetracosanol & 0.09 & $\left(\mathrm{n}-\mathrm{C}_{24} \mathrm{H}_{49} \mathrm{OH}(354.66)\right)$ \\
\hline & n-Hexacosanol & .01 & $\mathrm{n}-\mathrm{C}_{26} \mathrm{H}_{53} \mathrm{OH}(382.71)$ \\
\hline & n-Octacosanol & 0.01 & $\mathrm{n}-\mathrm{C}_{28} \mathrm{H}_{57} \mathrm{OH}(410.77)$ \\
\hline & n-Nonacosanol & 0.03 & $n-\mathrm{C}_{29} \mathrm{H}_{59} \mathrm{O}(424.79)$ \\
\hline & n-Triacontanol & 0.03 & $\mathrm{n}-\mathrm{C}_{30} \mathrm{H}_{61} \mathrm{OH}(438.82)$ \\
\hline & n-Dotriacontanol & & $\mathrm{n}-\mathrm{C}_{32} \mathrm{H}_{65} \mathrm{OH}(\mathbf{4 6 6 . 8 8})$ \\
\hline & n-Tetratriacontanol & 0.01 & $n-\mathrm{C}_{34} \mathrm{H}_{69} \mathrm{OH}(494.93)$ \\
\hline \multicolumn{4}{|c|}{ Fatty carboxylic acids } \\
\hline & n-Tetracosanoic & 0.02 & $\mathrm{C}_{24} \mathrm{H}_{48} \mathrm{O}_{2}(368.64)$ \\
\hline & n-Hexacosanoic & 0.02 & $\overbrace{\mathrm{C}_{26} \mathrm{H}_{52} \mathrm{O}_{2}(396.70)}$ \\
\hline & n-Octacosanoic & $\mathbf{0 . 0 3}$ & $\begin{array}{l}\mathrm{CH}_{3}\left(\mathrm{CH}_{2}\right) 26 \mathrm{CO}_{2} \mathrm{H} \\
\mathrm{C}_{28} \mathrm{H}_{56} \mathrm{O}_{2}=424.75\end{array}$ \\
\hline & n-Nonacosanoic & 0.01 & $\begin{array}{l}\mathrm{CH}_{3}\left(\mathrm{CH}_{2}\right) 27 \mathrm{CO}_{2} \mathrm{H} \\
438.8 \mathrm{C}_{29} \mathrm{H}_{58} \mathrm{O}_{2}\end{array}$ \\
\hline & n-Triacontanoic & 0.01 & $\mathrm{C}_{30} \mathrm{H}_{60} \mathrm{O}_{2} 452.46$ \\
\hline
\end{tabular}

The isolation of sugarcane waxes from filter cake mud was carried by extraction of the mud by four solvents (n-hexane, methylene chloride, ethanol and toluene).

When press mud of sugarcane was extracted with methylene chloride, the crude waxes produced equal to $7.67 \%$ relative to the mud weight used and its melting point $79^{\circ} \mathrm{C}$. The produced wax was identified by different analyses. Its IR showed absorption bands at 
$3418.95 \mathrm{~cm}^{-1}$ (OH group), $2917.56 \mathrm{~cm}^{-1}$ (CH aliphatic), and 1736.99 $\mathrm{cm}^{-1}$ (CO group).

Its ${ }^{1} \mathrm{H}$ NMR $90 \mathrm{MHz}\left(\mathrm{CDCl}_{3}\right): \delta=0.9\left(\mathrm{t}, 3 \mathrm{H}, \mathrm{CH}_{3}\right)$ and at $1.3(\mathrm{~m}$, 54H, $\left.27 \mathrm{CH}_{2}\right) .{ }^{1} \mathrm{H}$ NMR $400 \mathrm{MHz}\left(\mathrm{CDCl}_{3}\right): \delta=0.9\left(\mathrm{t}, 3 \mathrm{H}, \mathrm{CH}_{3}\right)$, $1.3\left(\mathrm{~m}, 54 \mathrm{H}, 27 \mathrm{CH}_{2}\right)$ and at $3.6\left(\mathrm{CH}_{2}-\mathrm{OH}\right)$.

Mass spectra: Base peak at $\mathrm{m} / \mathrm{z} 97.2$ and molecular ion peak at $\mathrm{m} / \mathrm{z}=552.8$, and other (fragments at 43,1, 57.1, 69.1, 83.1, 111.2, 125.2, 139.2, 153.2, 181.2, 209.3, 236.3, 264.3, 292.4, 320.4, 364.4, 392.5, 414.4, 440.5, 470.6, 501.8, 523.1, 552.8).Peaks at $\mathrm{m} / \mathrm{z} 410$ and 392 due to octacosanol and its dehydrated 1-octacosene, respectively.

But when the mud was extracted with ethanol (95\%), the waxes yield equal $4.81 \%$ yield, melting point $78{ }^{\circ} \mathrm{C}$. its IR showed absorption bands at $3363.47 \mathrm{~cm}^{-1}$ broad band $(\mathrm{OH}), 2917.23 \mathrm{~cm}^{-}$ ${ }^{1}$ (CH aliphatic), $1716.20 \mathrm{~cm}^{-1}$ (CO group). Its ${ }^{1} \mathrm{H}$ NMR $90 \mathrm{MHz}$ $\left(\mathrm{CDCl}_{3}\right): \delta=0.9\left(\mathrm{t}, 3 \mathrm{H}, \mathrm{CH}_{3}\right)$ and at $1.3\left(\mathrm{~m}, 54 \mathrm{H}, 27 \mathrm{CH}_{2}\right)$.

Extraction of press mud with hexane, the weight of wax extracted is $1.71 \mathrm{~g}$

$\%$ Waxes $=1.71 / 67.77 \times 100=2.52 \%$ yield, melting point $83^{\circ} \mathrm{c}$

IR: $v=3422.01 \mathrm{~cm}^{-1}$ broad band $(\mathrm{OH}), 2917.73 \mathrm{~cm}^{-1}(\mathrm{CH}$ aliphatic $)$, $1735.81 \mathrm{~cm}^{-1}$ (CO group).

${ }^{1} \mathrm{H} \mathrm{NMR} 90 \mathrm{MHz}\left(\mathrm{CDCl}_{3}\right): \delta=0.9\left(\mathrm{t}, 3 \mathrm{H}, \mathrm{CH}_{3}\right)$ and at $1.3(\mathrm{~m}, 54 \mathrm{H}$, $27 \mathrm{CH}_{2}$ ).

${ }^{1} \mathrm{H}$ NMR $400 \mathrm{MHz}\left(\mathrm{CDCl}_{3}\right): \delta=0.9\left(\mathrm{t}, 3 \mathrm{H}, \mathrm{CH}_{3}\right), 1.3(\mathrm{~m}, 54 \mathrm{H}, 27$ $\left.\mathrm{CH}_{2}\right)$ and at $3.6\left(\mathrm{CH}_{2}-\mathrm{OH}\right)$.

Mass spectra: Base peak at m/z 410 and 392 due to octacosanol and its dehydrated octacosene respectively. Other $\mathrm{m} / \mathrm{z}$ for heptacosanol and hexacosanol also present

Extraction of press mud with toluene produce $4.79 \%$ waxes. That is relative to the weight of mud used and its yield, melting point $74{ }^{\circ} \mathrm{C}$. The analyses of produced waxes is as follows: IR showed absorption bands at $3381.96 \mathrm{~cm}^{-1}$ as a broad band's characteristic for $(\mathrm{OH})$ alcoholic and carboxylic $\mathrm{OH}$, at $2917.33 \mathrm{~cm}^{-1}$ (CH aliphatic), and at $1715.46 \mathrm{~cm}^{-1}$ (CO group) of carboxylic group. Its Gas mass give a base peak at 57.1 and molecular ion peak at 429, and other fragments at393,390,and 364. Its ${ }^{1} \mathrm{H}$ NMR $90 \mathrm{MHz}$ 
$\left(\mathrm{CDCl}_{3}\right)$ showed a signals at $0.9\left(\mathrm{t}, 3 \mathrm{H}, \mathrm{CH}_{3}\right)$ and at $1.3(\mathrm{~m}, 54 \mathrm{H}, 27$ $\mathrm{CH}_{2}$ ).

\section{Conclusion}

Isolation the sugarcane waxes from either sugarcane peels or the press mud which considered as waste in the sugar industry. The sugarcane waxes is considered as added value to the sugar industry specially those which isolated from the press mud. Whereas the crude waxes produced reaches to $85 \%$ relative to the weight of press mud used. From waxes analyses we conclude that is a mixture of long chain fatty acids and long chain alcohols.

\section{References}

[1] Ali Abdi ; Ahmed Wally (2018), Sugar Annual.

[2] Mangesh B. Inarkar and S. S. Lele (2012); International Scholarly Research Network ISRN Agronomy; pages 1-6.

[3] P. Georges, M. Sylvestre, H. Ruegger, and P. Bourgeois (2006), "Ketosteroids and hydroxyketosteroids, minor metabolites of sugarcane wax," Steroids, 71(8) pp. 647-652.

[4] A. K. Taylor (2000), "From raw sugar to raw materials," Chemical Innovation, 30(11), pp. 45-48.

[5] Carina Nazato; Nádia Hortense Torres Suellen Catarina Urias Ferraz; Franz ZirenaVilca; Daniela Ferraz de Campos Silva; Claudio Lima de Aguiar; Marcia Nalesso Costa Harder(2012); American Journal of Biochemistry, 2(5): 89-93.

[6] Paturau, J. M. Bagasse(1969): By products of the sugar cane industry. Elsevier, USA,

[7] Laguna Granja, A., Magraner Hernandez, J., Carbajal Quintana, D., ArruzazabalaValmana, L., Mas Ferreiro, R., Garcia Mesa, M. (1999). A mixture of higher primary aliphatic alcohols, its objection from sugar cane wax and its pharmaceutical uses. US patent No. 5856316. 
[8] Mas, R., Rivas, P., Izquierdo, J.E., Hernandez, R., Fernandez, J., Orta, S.D., Illnait, J., Ricardo, Y., (1999). Pharm acoepidemiologic study of polycosanol. Curr. Ther. Res. 60, 458-467.

[9] Paturau, J.M. (1989) By-Products of the Cane Sugar Industry, 3rd ed. Elsevier, Amsterdam, The Netherlands.

[10] Lamberton, J.A. (1965). Long-chain aldehydes of sugarcane wax. Aust. J. Chem. 18, 911-913.

[11] Lamberton, J.A., Redcliffe, A.H. (1960). The chemistry of sugar-cane wax. I. The nature of sugar cane wax. Aust. J. Chem. 13, 261-268.

[12] Parfait, A., Namory, M., Dubois, P.(1972). Ethyl esters of the higher fatty acids of rum. Ann. Technol. Agr. 21, 199-210.

[13] Askew, S., Bowden, B., Ridd, M., Valix, M. (1999). Analysis of sugarcane using high temperature GC-MS. In: Proceedings of the $21^{\text {st }}$ Conference of the Australian Society of Sugar Cane Technologists, pp. 389-393.

[14] Gladys Nuissier, Paul Bourgeoisa, Micheline GrignonDubois, Patrick Pardon, Marie Helene Lescure (2002); Photochemistry, 61, 721-726. 


\section{المنص العربي}

\section{نصل وتنقية شمع قصب السكر هن قشر قصب السكر وطينة المرشحات}

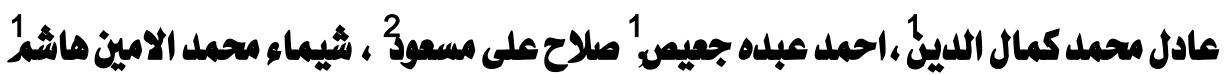

$$
1 \text { فسمالكيمياء - كلية العلوم - بامعة اسيوط - مصر }
$$

يعتبر قصب السكرمن النباتات الاقتصادية المهمة. تبلغ المساحة المزروعة مع قصب السكر في مصر حوالي 125000 هكتار = 297619.047 فدان تنتج حوالي 12.5 مليون

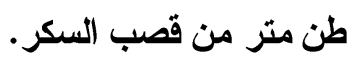

تحاول الثركة المصرية للسكرو الصناعات التكاملية الاستفادة الى حد كبيرمن جميع مكون قصب السكر • واستخدام جميع المنتجات الثانوية الناتجة من صناعة السكر حيث يتم استخدام المصاصة لقصب السكركمو اد خام فى صناعة الورق و الألياف. والمولاس يستخدم في إنتاج مواد كيميائية مهمة بمختلف انواعها (الإيثانول ،الأسيتون ،حض الخليك، البيوتانول ، الخمائر) و غيرها من المواد الكيميائية. وتستخدم طينة المرشحات كسماد. في ضوء سياسة شركة السكر وسياسة كلية تكنولوجيا صناعة السكر وجلنا

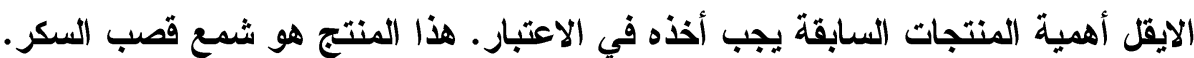
وهوعبارة عن طبقه لونها أبيض مائلة للاصفر ار موجودة على سطح قصب السكر، يتم

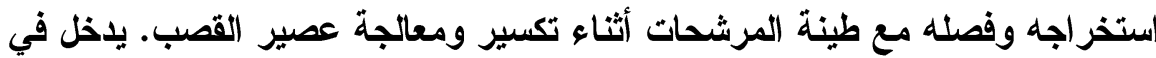

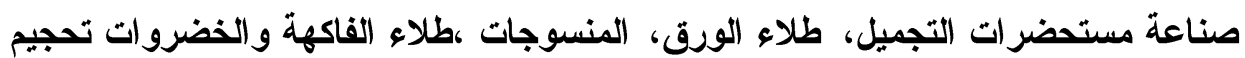
الجلود، مواد التشحيم، المواد اللاصقة، ملمعات والأدوية.

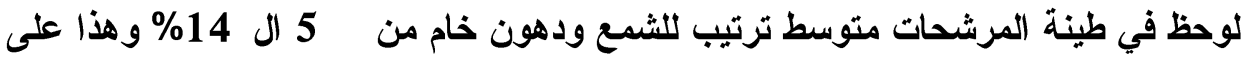
اسس موضوعية مع بعض المقترحات المختلفة لاستخدامها ولكن غالبا ما يتم ارسالها الى ملى

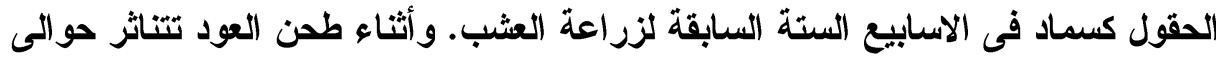
40 \% من المواد الدهنية فى العصير كراسب بينما يتم الاحتفاظ بالباقي فى اللب بعد

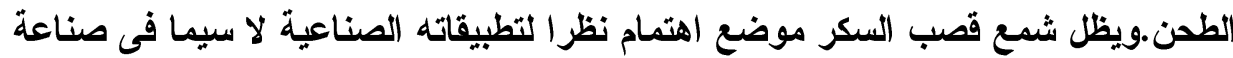

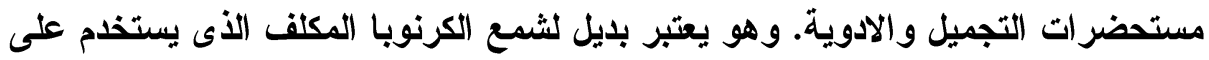


قار واسع في مستحضر ات التجميل والادوية. بالإضافة الى ذللك شمع قصب السكر يعتبر ايضا مصدر للكحوليات الاليفاتية ذات سلسلة احادية طويلة . البوليكوسانول عبارة عن مادة شمعية من الكحوليات عالية الايفاتية ذات سلسلة طويلة

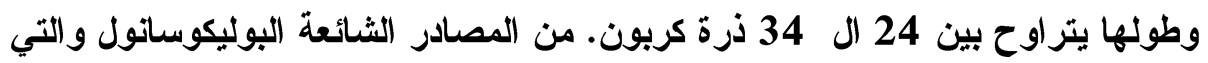

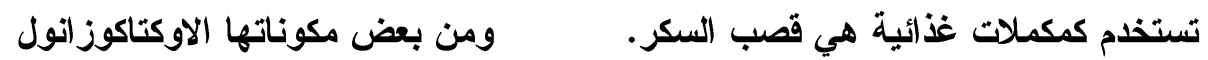
و الهيكساكوز انول والتراياكونتانول .وهذه المكونات تمت المواققة عليها لاول مرة كمكملات غذائية ولها تطبيقات عديدة منها انخفاض مستوى الكوليسترول فى الام. اثناء عملية التصنيع جزء كبير من الثمع يأوب فى العصير الخام ثم يتم ازالته فى النفايات اثناء خطوة تنقية وترويق المعلق( طينة المرشحات من صناعة السكر) اواثناء التقطير . الاوكتاكوز انول يعتبر مكون إساسي في البوليكوسانول وهو مخلوط دهن دهني من من الكحوليات وموجود في الثموع النباتية والفو اكه والاوراق واسطح النباتات و البذور الكامليكة.

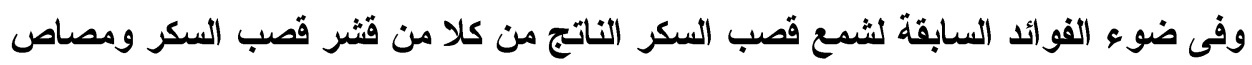

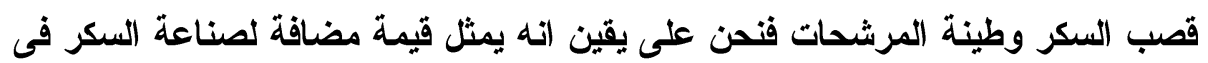
مصر

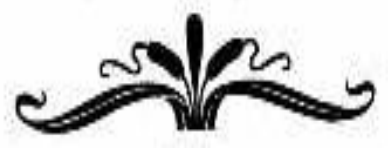

